\title{
PRELIMINARY TESTING OF THE ECOLOGICAL INTERACTIONS BETWEEN PINES AND OAKS OF CONIFEROUS FORESTS OF DURANGO, MEXICO
}

\author{
José de Jesús Návar Cháidez 1
}

\begin{abstract}
In this paper it was tested the independence of diameter structures of oak and pines sharing resources in forest stands of the western Sierra Madre mountain range of Durango, Mexico with the aim to detect ecological interactions between these two genera. Regression analysis was conducted on the weibull distribution parameters fitted independently to diameter structures of pines and oaks. The moments methodology of parameter estimation of the Weibull distribution was fitted. This procedure was independently carried out for pine and oak diameter structures of mixed and uneven-aged forests. The regression analysis conducted on the weibull parameters for pines and oaks did not show patterns or tendencies with sufficient statistical meaning. Indeed the diameter structures of pines and oaks are quite similar and showed little sensitivity to changes in the weibull parameters stressing the potential independence of diameter growth of pines and oaks. Further research is required to understand the ecological interactions between oaks and pines, at the species scale, with the aim to develop growth and yield models to sustainable manage the mixed, uneven-aged coniferous forests of Durango, Mexico.
\end{abstract}

Keywords: Diameter structures, Weibull distribution, moments

\section{PRUEBAS PRELIMINARES DE LAS INTERACCIONES ECOLOGICAS ENTRE LOS PINOS Y LOS ENCINOS DE BOSQUES DE CONIFERAS DE DURANGO, MEXICO}

\begin{abstract}
RESUMEN
En este reporte se probó la independencia de las estructuras diamétricas de pinos y latifoliadas compartiendo los bosques de la Sierra Madre Occidental de Durango, México, con el objetivo de detectar relaciones ecologicas entre estos dos géneros. Se realizaron análisis de regresión entre los parámetros de la distribución weibull, ajustados independientemente a las estructuras diamétricas de pinos y latifoliadas. Se usó la metodología de momentos para estimar los parámetros de la distribución Weibull. Este procedimiento se realizó independientemente para las estructuras diamétricas de pinos y latifoliadas de los bosques mixtos e irregulares de Durango, México. Los análisis de regresión, realizados entre los parámetros de la distribución Weibull, no mostraron tendencias o patrones con significado estadístico suficiente. Las estructuras diamétricas de pinos y latifoliadas son muy similares y mostraron baja sensibilidad a los cambios en los parámetros de la distribución Weibull estresando la potencial independencia en el crecimiento diamétrico de pinos y latifoliadas. Se requiere investigación adicional para entender las interacciones ecológicas entre las latifoliadas y los pinos, a la escala de especie, con el objetivo de desarrollar modelos de rendimiento e incremento para manejar sosteniblemente los bosques mixtos e irregulares de coníferas de Durango, México.

Palabras-clave: Estructuras diamétricas, Distribución Weibull, momentos
\end{abstract}

\section{INTRODUCTION}

Coniferous forests of the Western Sierra Madre mountain range of Durango, Mexico are mixed and uneven-aged in nature. In the south central portion of the Sierra, at the ejido property, with an average area of approximately 20,000 ha, 41 tree species

were observed, regardless on the difficulty to taxonomically identifying species of the genus Quercus. At the forest stand scale, Graciano (2001) observed an average of six different tree species using a simple classification scheme for oaks.

\footnotetext{
${ }^{1}$ Professor of Forestry \& Watershed Management. Facultad de Ciencias Forestales, UANL. Km. 145 Carr. Nal. Linares, N. L. 67700 México. E-mail: jnavar@ccr.dsi.uanl.mx
}

Recebido para publicação: 28/01/2004

Aceito para publicação: 14/10/2004 
Regardless of the tree diversity of these forests, historically they had been managed considering exclusively pine trees in harvesting schedules. Oaks, and other broadleaf species, were considered as competitors for space and resources and they were severed on site or eliminated to favour the establishment and to increase density and growth of pine trees. Recently oak trees are the focus of harvesting programs in several regions of the sierra. These human interventions may have shifted forest succesion and probably changed tree diversity. Only other coniferous trees of the genus Picea, Pseudotsuga, Abies, and Cupressus are isolated from harvesting schedules because of the government regulations on the rare and endangered species act (NOM 059 Ecol-1994-2001).

Vanclay (1994), and Boyle and Boontawee (1997) stressed the need to develop growth and yield models for native, mixed forests considering biological diversity issues since several human interventions, specifically selective logging, grazing, plantations with exotic species, and burning, can change biodiversity (Stork et al. 1997). Selective logging has been found to alter the diversity abundance of coniferous forests (Graciano, 2001). Subtle changes in diversity may alter succesion and growth rithms of remnant species, since the ecological interactions between tree species or genera are not well understood in mixed forests. The first step in developing growth and yield models is to understand the ecological interactions between the species present in mixed forests (Vanclay, 1994).

In this research we tested the hypothesis that pine and oak diameter structures develop independent of each other and this may form the basis for further growth and yield modeling.

\section{MATERIALS AND METHODS}

\section{The study area}

This research was conducted in the ejido San Pablo, located in the south central region of the Western Sierra Madre mountain range, in the municipality of Pueblo Nuevo, Durango, Mexico. The study site has the following coordinates $105^{\circ} 36^{\prime} 19^{\prime}$ ' and $105^{\circ} 51^{\prime} 48^{\prime \prime} \mathrm{W}$ and $24^{\circ} 19^{\prime} 05^{\prime \prime}$ and $24^{\circ} 30^{\prime} 16^{\prime \prime} \mathrm{N}$ with an altitude above sea level between 2000 and $2700 \mathrm{~m}$. Average annual long-term precipitation and temperature are $900 \mathrm{~mm}$ and $15^{\circ} \mathrm{C}$, respectively, with a temperate-cold climate.

The tree community of this region is quite complex. In the study area approximately 41 arboreal species were recorded in the last forest inventory. The genus Pinus dominates the landscape with $75 \%$ of the total tree diversity. Common pine species and relative abundance are $P$. durangensis (37\%), P.cooperi (16\%), P. teocote $(9 \%), P$. leiophylla (4\%), P. ayacahuite (3\%), P. engelmannii (2\%). Other pine species less abundant are: $P$. herrerai, $P$. lumholtzii, $P$. oocarpa, $P$. duglasiana, $P$. michoacana, $P$. chihuahuana and $P$. maximinoi. Other conifer trees found are Junniperus spp, Cupressus spp, Pseudotsuga menziesii, Picea chihuahuana and Abies durangensis and they make up $1.3 \%$ of the tree diversity. The oak species account for a little over $20 \%$ of the tree diversity and dominant species are: Q. rugosa, Q. crassipes, Q. fulva, Q. crassifolia, Q. obtusata, $Q$. sideroxyla, $Q$. laeta, $Q$. striatula, $Q$. durifolia (González and Gonzalez, 1995). Other important tree species recorded are: Arbutus spp, Alnus firnifolia, Fraxinus spp and Populus wislizenii. Dry tropical forest species are present in the lowlands but they are not reported because they account for less than $0.1 \%$ of the total abundance. Dasometric characteristics of all present trees are quite homogeneus (table 1).

Table 1: Average dasometric characteristics for 587 mixed and uneven-aged forest stands of Durango, México Tabla 1: Las características dasométricas promedio para 587 rodales con bosques mixtos e irregulars de Durango, México

\begin{tabular}{llcccc}
\hline Sample No & $\begin{array}{c}\text { Group of } \\
\text { Genera }\end{array}$ & $\begin{array}{c}\text { Total Number of } \\
\text { trees }\end{array}$ & $\begin{array}{c}\text { Average quadratic } \\
\text { diameter(cm) }\end{array}$ & $\begin{array}{c}\text { Standard Deviation } \\
(\mathrm{cm})\end{array}$ & $\begin{array}{c}\text { Skew } \\
\text { coefficient }\end{array}$ \\
\hline \hline Total & Pinus & 63158 & 23.4 & 8.7 & 1.4 \\
& Oaks & 21237 & 23.7 & 12.8 & 2.1 \\
\hline
\end{tabular}




\section{Methodology}

The information was collected in a conventional forest inventory sampling 587 forest stands. In total 1950 temporary, circularsampling units, with $1000 \mathrm{~m}^{2}$ each were established in a stratified-systematic manner. More than three sampling sites were established in each forest stand. In each sampling plot, each tree of all species was measured in diameter at breast height $(\mathrm{DBH})$, top height $(\mathrm{H})$, canopy cover $(\mathrm{Cc})$, species $(\mathrm{S})$ and sociological position (SP). Age was measured in 3-5 trees in each sampling plot.
The weibull distribution has been succesfully fitted and validated to diameter structures of mixed, uneven-aged, forests of Durango, Mexico (Návar and Contreras, 2000; Návar and Corral, 2000). In this research it was used the moments methodology of parameter estimation because Návar and Contreras (2000) and Návar and Corral (2000) stressed that small differences in hypothesis testing were observed between maximum likelihood and moment procedures.

The weibull distribution, as a probabilistic density function (pdf) is given by model 1 (Haan, 1986);

$\operatorname{Px}(X)=\left(\frac{\alpha}{\beta}\right)\left(\frac{X-\varepsilon}{\beta}\right)^{\alpha-1} e^{\left(-\left(\frac{X-\varepsilon}{\beta}\right)^{\alpha}\right)}$

Where: $\mathrm{p}_{\mathrm{x}}(\mathrm{x})=$ probability of the random variable $\mathrm{x} . \alpha, \beta$ and $\varepsilon$ are shape, scale and location parameters, respectively.

Parameters $\alpha, \beta$ and $\varepsilon$ were estimated by the conventional procedure of moments (MNP). Hahn and Shapiro (1967) reported that the skew coefficient $(\gamma)$ is related to the shape parameter $(\alpha)$ by equation (2):

$\gamma=\frac{\Gamma(1+3 / \alpha)-3 \Gamma(1+2 / \alpha) \Gamma(1+1 / \alpha)+2 \Gamma^{3}(1+1 / \alpha)}{\left[\Gamma(1+2 / \alpha)-\Gamma^{2}(1+1 / \alpha)\right]^{3 / 2}}$

And with this they mathematically defined $\beta$ and $\varepsilon$ by models [3] and [4]:

$$
\begin{aligned}
& \beta=\left[\frac{\sigma^{2}}{\Gamma(1+2 / \alpha)-\Gamma^{2}(1+1 / \alpha)}\right]^{1 / 2} \\
& \varepsilon=\mu-\beta \Gamma(1+1 / \alpha) \ldots \ldots \ldots \ldots \ldots \ldots \ldots \ldots \ldots \ldots
\end{aligned}
$$

Where: $\mu$ and $\sigma$ are the average and standard deviation of the random variable, respectively. The shape parameter is iteratively fitted by estimating first the skew coefficient and working model [2] to latter solve for $\beta$ and $\varepsilon$.

The $\chi^{2}$ and Kolmoorov-Smirnoff (K$\mathrm{S})$ goodness of fit tests tested the null hypotesis of equal diameter distributions (observed and estimated).

\section{Procedure}

The weibull distribution parameters were fitted at the stand scale to pine and oak diameter structures by using the procedures described before. The first group of trees comprised all pine trees. Oak trees included the genus Quercus, Arbutus and Alnus.

The hipothesis that the diameter structures of pines and oaks develop independently was tested by regressing the estimated weibull parameters between oaks and pines. In addition, the diameter structures with average and average plus one standard 
deviation are illustrated to understand changes in the frequency distributions of diameter by changes in the parameters, as a type of sensitivity analysis.

\section{RESULTS AND DISCUSSION}

The parameters estimated by the moments procedure resulted in slightly different parameter estimators for $\alpha, \beta$ and $\varepsilon$ for both groups of species (table 2).

Table 2: Parameter estimators calculated by the methodology of moments for 587 mixed and uneven-aged forest stands of Durango, Mexico

Tabla 2: Estimadores de parámetros calculados por le metodología de momentos para 587 rodales de bosques mixtos e irregulars de Durango, México

\begin{tabular}{|c|c|c|c|c|c|c|c|c|c|c|c|c|}
\hline \multirow{4}{*}{ Genera } & \multicolumn{12}{|c|}{ Parameters of the weibull distribution } \\
\hline & \multicolumn{4}{|c|}{$\alpha$} & \multicolumn{4}{|c|}{$\beta$} & \multicolumn{4}{|c|}{$\varepsilon$} \\
\hline & \multicolumn{2}{|c|}{ Pinus } & \multicolumn{2}{|c|}{ Oaks } & \multicolumn{2}{|c|}{ Pinus } & \multicolumn{2}{|c|}{ Oaks } & \multicolumn{2}{|c|}{ Pinus } & \multicolumn{2}{|r|}{ Oaks } \\
\hline & A & SD & A & SD & A & SD & A & $\mathrm{SD}$ & A & SD & A & $\mathrm{SD}$ \\
\hline & 1.6 & 0.5 & 1.4 & 0.4 & 26.3 & 3.4 & 27.0 & 3.5 & 12.1 & 2.7 & 11.1 & 2.8 \\
\hline
\end{tabular}

$\mathrm{A}=$ average, $\mathrm{SD}=$ Standard deviation.

Estimated diameter structures fitted well the observed diameter structures for both groups of species, according to the goodness of fit tests of $\chi^{2}$ and K-S. The procedure of parameter estimation accepted on the average $63 \%$ of null hypothesis $(70.8,55.9$, for pines and oaks, respectively) with 0.05 confidence interval (figure 1). The K-S test improved the goodness of fit by approximately $30 \%$, with an average of $85 \%(89.9 \%$ and $82.6 \%$ for pine and oaks, respectively) (Figure 1). This finding has also been reported by Návar and Corral (2000) for several forest stands of Durango, Mexico.

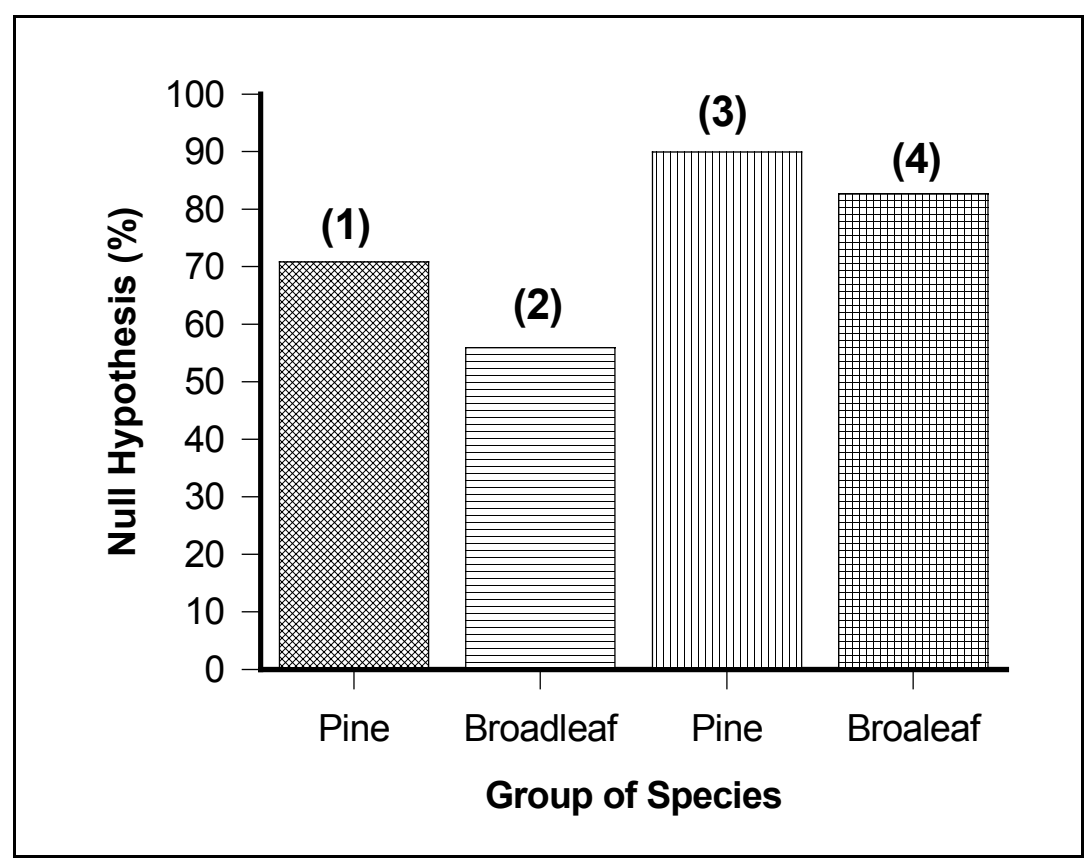

Figure 1: Goodness of fit tests of $\chi^{2}(1$ and 2) and K-S ( 3 and 4) conducted on the weibull distribution fitted to 587 forest stands of the Western Sierra Madre mountain range of Durango, Mexico

Figura 1: Pruebas de bondad de ajuste de $\chi 2$ (lllllll $\left.\begin{array}{lll}1 & 2\end{array}\right)$ y $-S\left(\begin{array}{lll}3 & \text { y } & 4\end{array}\right)$ realizadas sobre la distribución weibull ajustada a 587 rodales de la Sierra Madre Occidental de Durango, México 
Considering the $\chi^{2}$ test, the group of Pinus and oaks accepted a maximum percentage of null hypotheses of $76.5 \%$ and $60.1 \%$, respectively. For the rest $23.5 \%$ and $39.9 \%$ of forest stands with irregular diameter structures, it is recommended to fit other probabilistic distribution functios such as the Johnson SB. Other non-distributional approaches can predict the irregular frequency of these diameter structures. Borders and Patterson (1990) described a regression analysis approach to estimate diameter frequencies. However, if using this procedure, the relationships between parameters of regression equations must be conducted to understand the diameter structures of pines and oaks. Zarnoch and Dell (1985) and Nanag (1998) did not find statistical differences when comparing maximum likelihood with percentil and moment procedures of parameter estimation.

The dasometric parameters volume, average quadratic diameter, and average top height were not statistically related between pines and oaks (figure 2). In general, the volume for pines was higher (mean of $250 \mathrm{~m}^{3}$ $\mathrm{ha}^{-1}$ ), on the average, than the volume for oaks (mean $125 \mathrm{~m}^{3} \mathrm{ha}^{-1}$ ). However they recorded similar average quadratic diameter and top height (30 $\mathrm{cm}$ and $15 \mathrm{~m}$, respectively).

Stand density was statistically related in a negative linear manner between oaks and pines (figure 2). The linear regression predicts an oak density of 122 trees $\mathrm{ha}^{-1}$, when pines are absent in forest stands. However, when pine density increases to 500 trees $^{-1} \mathrm{ha}^{-1}$, oak density reduces to 77 trees $\mathrm{ha}^{-1}$ and when pine density increases to 1000 trees $\mathrm{ha}^{-1}$, oak density shrinks to 32 trees $\mathrm{ha}^{-1}$. That is, pine density is in general higher (mean of 400 trees $\mathrm{ha}^{-1}$ ) than oak density (mean of 75 trees $\mathrm{ha}^{-1}$ ). Two likely scenarios can be foreseen: (i) a downward oak density with an increasing altitude above sea level; and (ii) oaks, as late successional species, dominate the landscape after harvesting practices diminished pine density. Because of the low oak density, pines, in general shade intolerant species, can establish in oak forest stands with small tree density. Indeed, Graciano (2001) observed that oaks and pines appear to share forest stands in a similar proportion between 2000-2500 masl but above 2500 masl, pines dominate the landscapes of the sierra.

The shape, scale and location parameters, of the weibull distribution were not statistically related between oaks and pines (figures 3,4,5). The estimated diameter structures, with average weibull parameters, distribute in a similar way between oaks and pines. When subtracting one standard deviation to the shape parameter for oaks and pines, the diameter distribution shifted towards a type of Licourt curve; increasing the irregularity of oak and pine forests (figure 3 ). When adding its standard deviation to the shape parameter, the diameter structures for pines and oaks shifted towards a more symetric type of frequency distribution (Figure 3).

The scale and location parameters were not related either between oak and pine diameter structures (figures 4 and 5). The frequency distributions were not highly sensitive to changes in the scale and location parameters. When adding its standard deviation to the location parameter the frequency distribution displaced to the right of the diameter structure. The magnitude of displacement matches the value of the standard deviation added to the location parameter.

This research demonstrates that the current diameter structures of pines and oaks distribute independently of each other and the frequency distributions are quite similar in mixed forests of the Sierra Madre Occidental mountain range. The frequency distributions were similar between oaks and pines and quite insensitive to changes in the weibull parameters. Therefore this research leads to the conclusion that pines and oaks are present and appear to grow independently with likely succesional stages, which cannot be supported by this data. These observations are consistent with the findings reported by Dominguez and Navar (1993), who recorded that by eliminating oak trees from a mixed stand and leaving only pine trees, reducing the basal area to $50 \%$, remnant pines, with an average age of 40 years, would not enhance diameter growth neither would promote the succesfull establishment of natural pine regeneration (De Los Ríos, 2001).

On the other hand, research on the ecological role of oaks has demonstrated a 
potential long term succesional theory in mixed forests of the eastern Sierra Madre Mountain range of Nuevo Leon, Mexico (Eckelmann, 1995). This researcher noted that pines regenerate more successfully under the canopy of oaks and this effect was attributed to matted leaves, which easily funnel pine seeds down into the mineral soil in the presence of rain. Pine litter, on the other side, forms a barrier between seeds and the mineral soil and therefore limits the establishment of pine natural regeneration. On the other side,
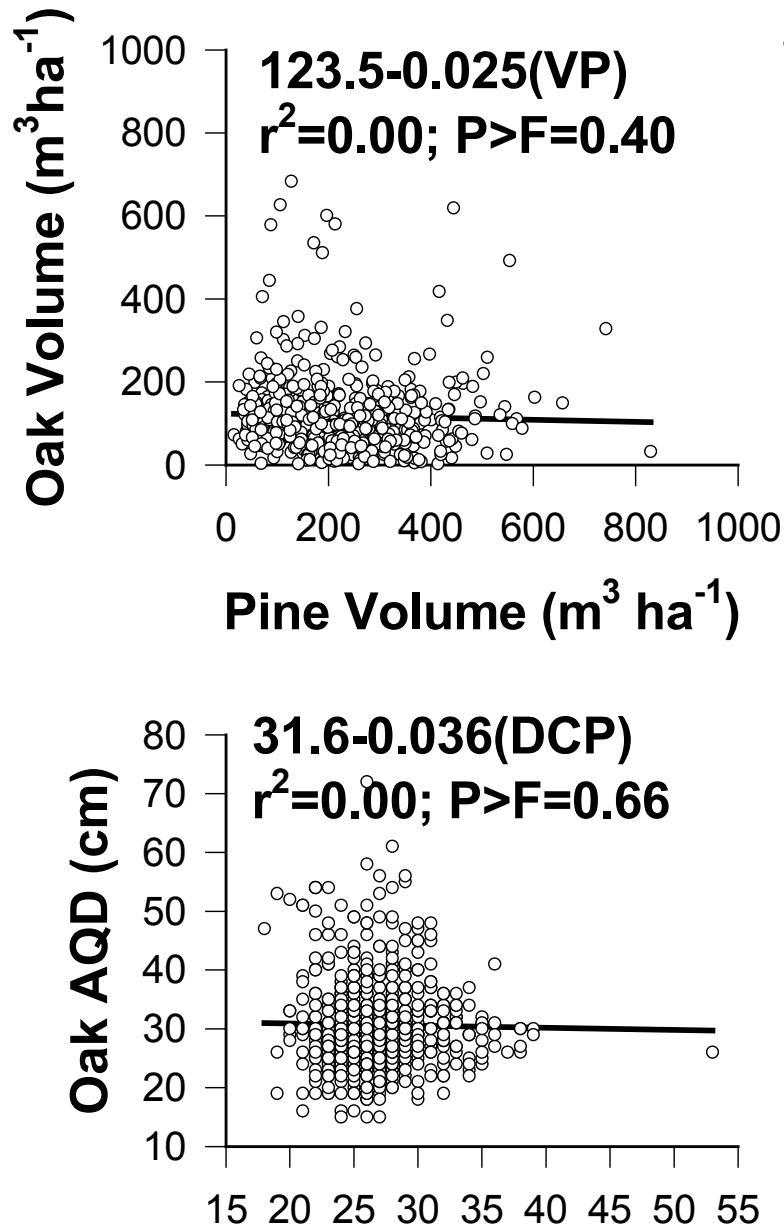

Pine AQD (cm)
González et al. (1995) and Richardson and Bond (1991) stressed that human disturbances such as, selective cutting of oaks and overgrazing practices favour the establishment of pine trees and impoverish oak abundance and diversity. Our findings, if reviewed at the individual species between genera, may shed more ligth into the ecological interactions between pines and oaks and the effect of human disturbance on the succesional processes. This requires additional research, which must be conducted to comply with the criteria and indicators for assessing the sustainability of forest management in terms of the conservation of biodiversity (Stork et al., 1997).
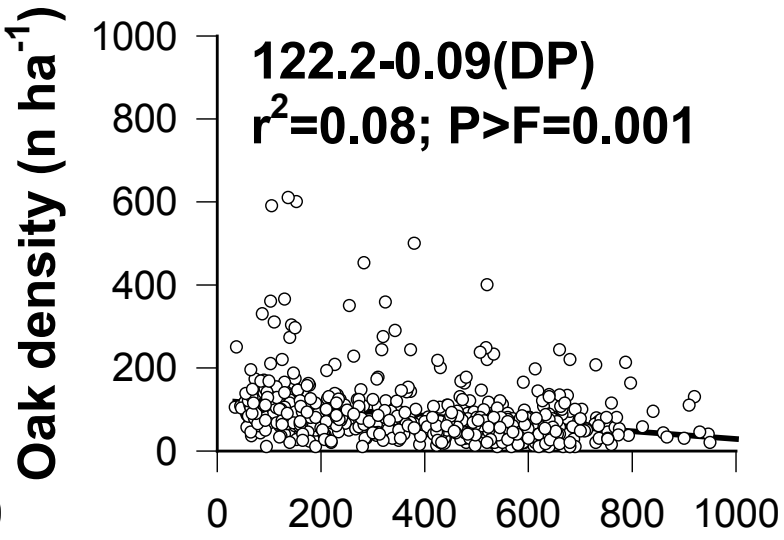

Pine Density $\left(\mathrm{n} \mathrm{ha}^{-1}\right)$

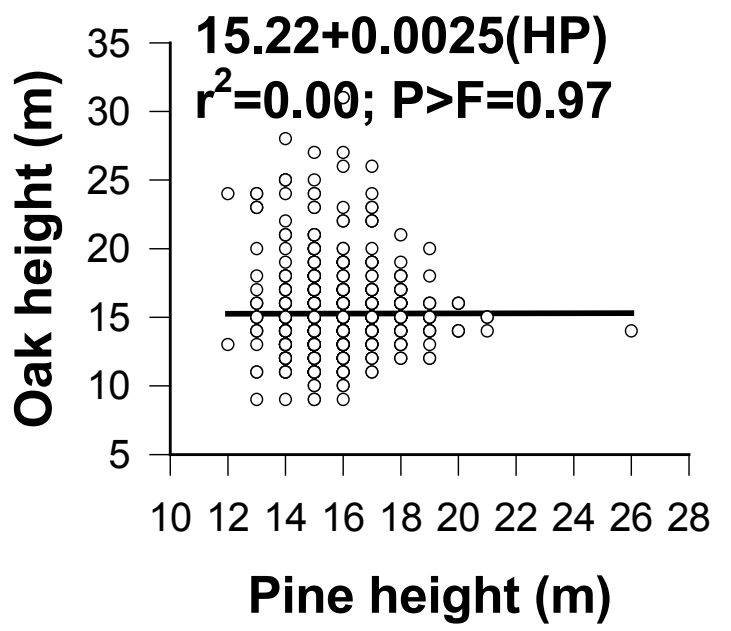

Figure 2: Average pine and oak dasometric characteristics of 587 mixed forest stands of Durnago, México Figura 2 Las características dasométricas de pinos y encinos de 587 rodales mixtos de Durango, México 


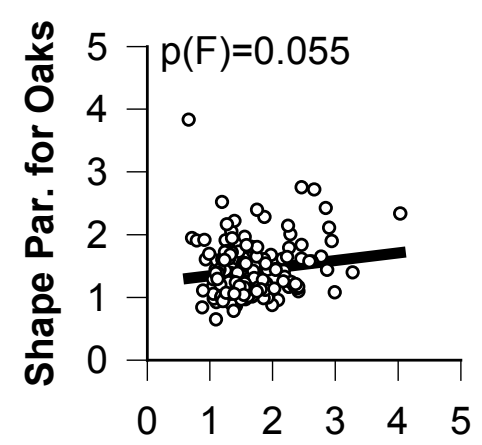

Shape Par. for Pines

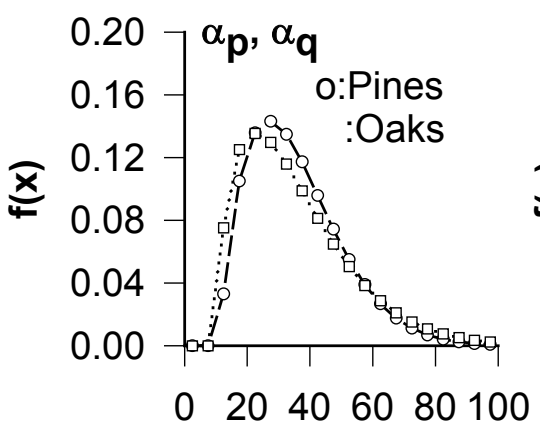

Diameter (cm)

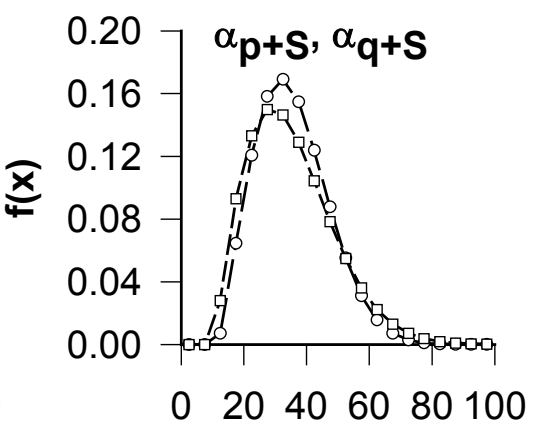

Diameter (cm)
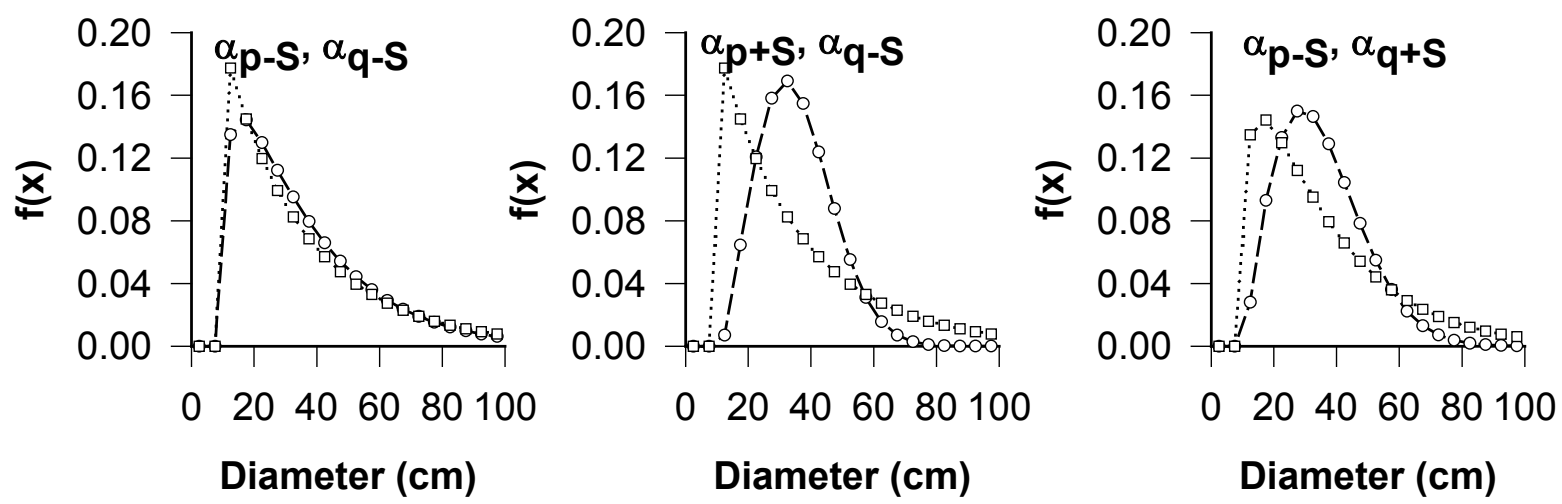

Figure 3: Scenarios for the shape parameter of the weibull distribution between pines and oaks of mixed forest stands of Durango, México

Figura 3: Los escenarios para el parámetro de forma de la distribución weibull entre pinos y encinos de rodales mixtos de Durango, México 

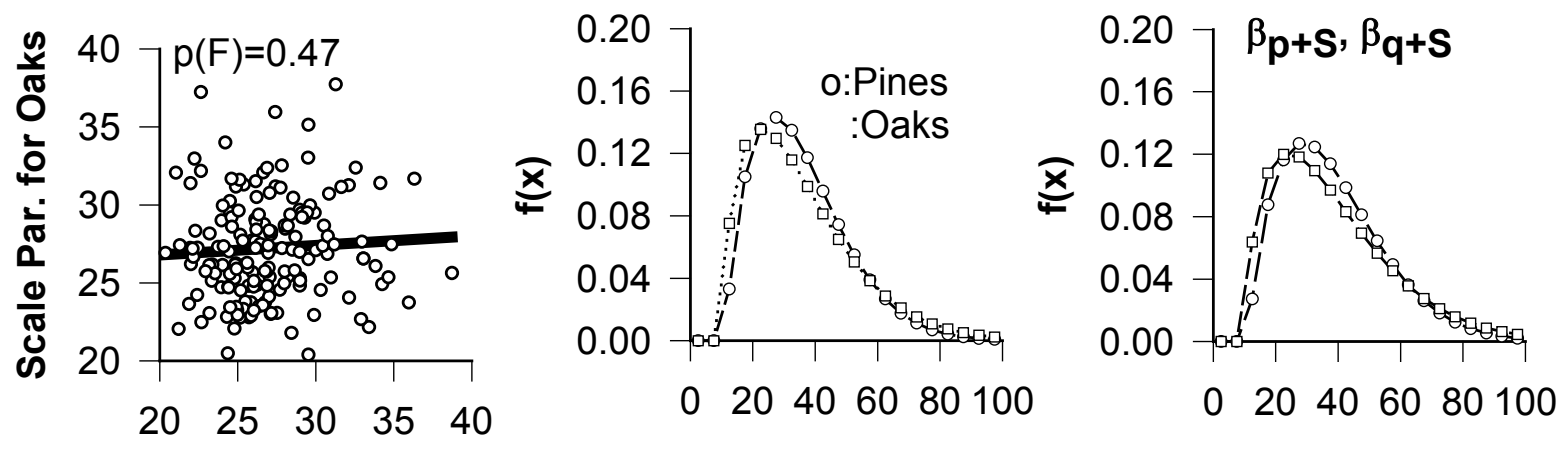

Scale Par. for Pines
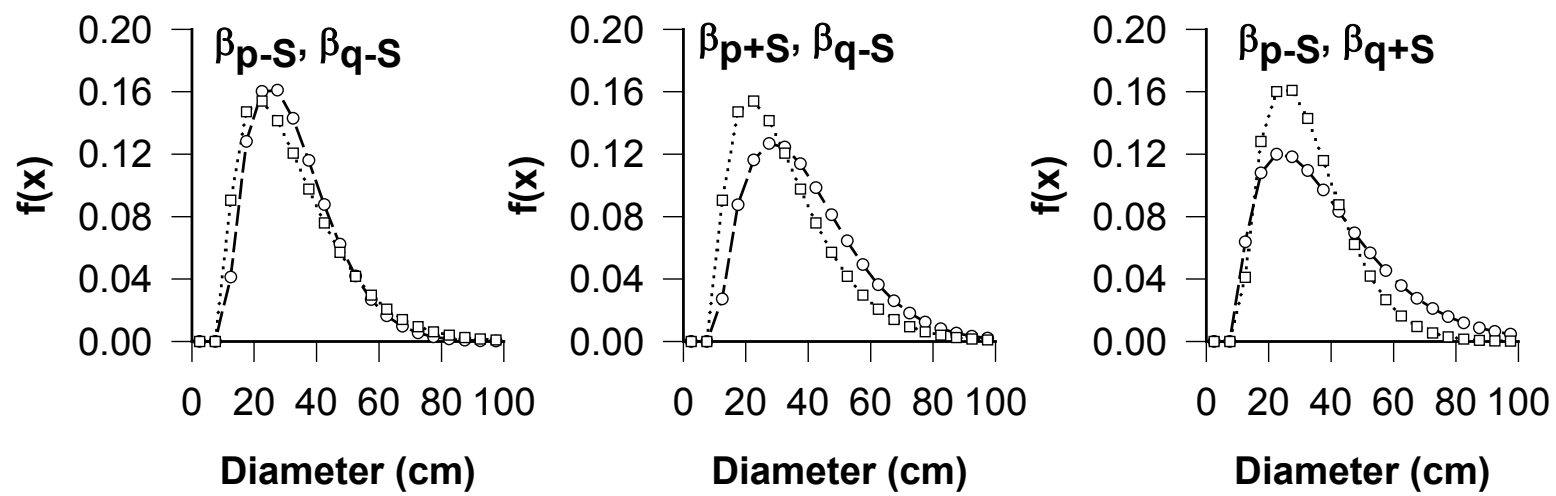

Figure 4: Scenarios for the scale parameter of the weibull distribution between pines and oaks of mixed forest stands of Durango, México

Figura 4: Los escenarios para el parámetro de escala de la distribución weibull entre pinos y encinos de rodales mixtos de Durango, México 


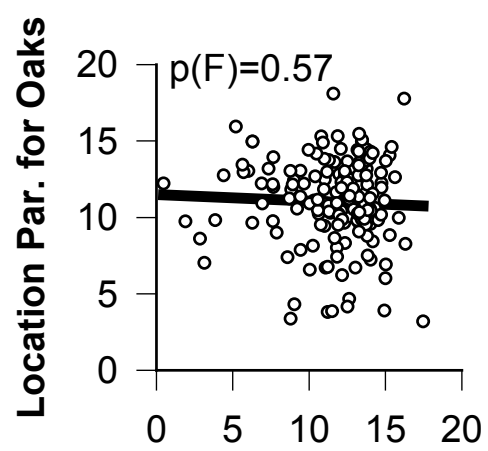

Location Par. for Pines

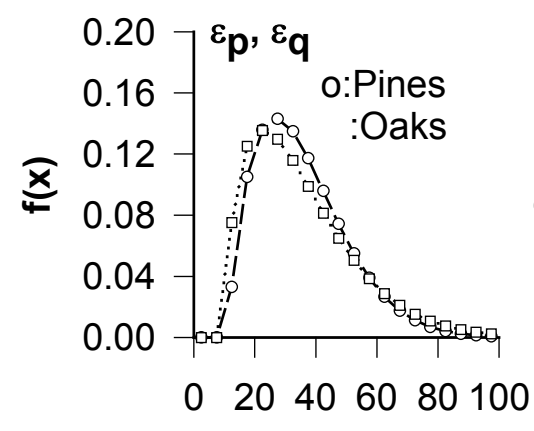

Diameter (cm)

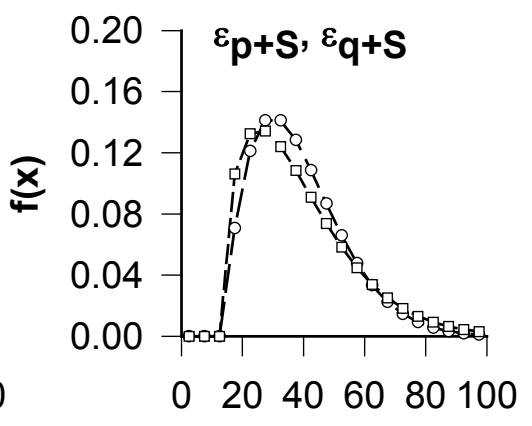

Diameter (cm)

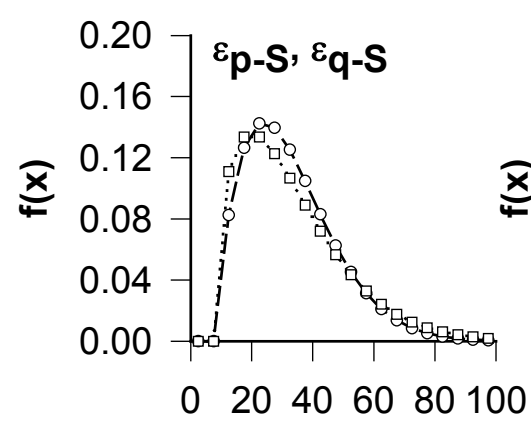

Diameter (cm)

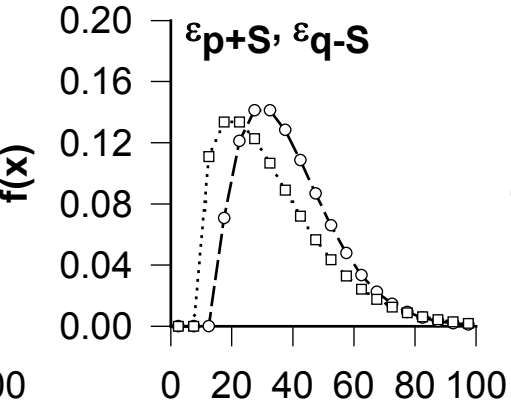

Diameter (cm)

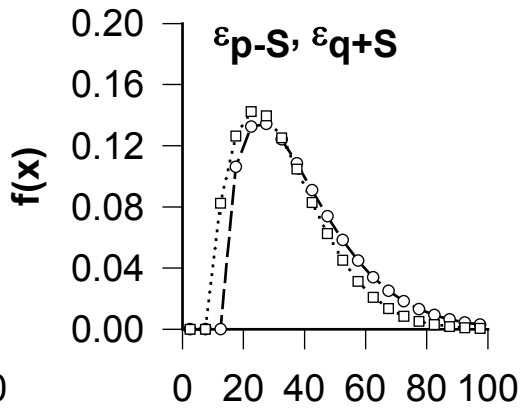

Diameter (cm)

Figure 5: Scenarios for the location parameter of the weibull distribution between pines and oaks of mixed forest stands of Durango, México

Figura 5: Los escenarios para el parámetro de posición de la distribución weibull entre pinos y encinos de rodales mixtos de Durango, México

\section{CONCLUSIONS}

The diameter structures were not statistically related between pines and oaks stressing the potential independence on diameter growth of these two dominant tree genera characeristic of the mixed, uneven-aged coniferous forests of the south central portion of the western Sierra Madre mountain range of Durango, Mexico. Additional research is required to prove the independence of diameter growth of these two genera at the species scale with the aim to sustainable manage these forests.

\section{ACKNOWLEDGMENTS}

The CONACyT and PAICyT partially funded this research through grants 28536-B and CT203-99, respectively.

\section{REFERENCES}

Boyle, T.J.B. and B. Boontawee. 1997. Measuring and Monitoring Biodiversity in Tropical and Temperate Forests. Center for International Forestry Research.Jakarta, Indonesia. $115 \mathrm{p}$.

De Los Ríos, C.E. 2001. Efectos de la intensidad de corta y tratamientos al suelo en la regeneración natural de Pinus psedostrobus Lindl., en el ejido Purisima, Iturbide, Nuevo León, México. Tesis Profesional de Ingeniería Forestal. Facultad de Ciencias Forestales-UANL. Linares, N.L., México. 100 p. 
Domínguez, P.A. and J. Návar. 1993. El efecto de los aclareos en el crecimiento radial en un bosque de pino-encino en Iturbide, Nuevo León. Resumen de Ponencias. I Congreso Mexicano sobre Recursos Forestales. p. 38. Saltillo, Coahuila, México.

Eckelmann, C.M. 1995. Regeneración y dinámica natural de un bosque de pinoencino en la sierra madre oriental en el nordeste de México. Memorias. III Seminario Nacional sobre Utilización de Encinos. Linares, N.L., 4-6 Noviembre de 1992. p199212.

González, E.M., N.M. Ramírez, P.F. Quintana, and M. Martínez. 1995. La utilizaciónd de los encinos y la conservación de la biodiversidad en los Altos de Chiapas. Memorias. III Seminario Nacional sobre Utilización de Encinos. Linares, N.L., 4-6 Noviembre de 1992. p183-194.

González, S.E. and M. González. 1995. Los encinos de Durango, México. Memorias. III Seminario Nacional sobre Utilización de Encinos. Linares, N.L., 4-6 Noviembre de 1992. P28-33.

Graciano, L.J. 2001. Técnicas de evaluación dasométrica y ecológica de los bosques de coníferas bajo manejo de la Sierra Madre Occidental del centro sur de Durango, México. Tesis Profesional de Maestría en Ciencias. Facultad de Ciencias ForestalesUANL. Linares, N.L., México.

Haan, C.T. 1986. Statistical Methods in Hydrology. Iowa State Press. 378 p.

Hahn, G.J. and S.S. Shapiro. 1967. Statistical Models in Engineering. John Wiley and Sons, New York. 418 p.
Nanang D.M. 1998. Suitability of the Normal, Log-normal and Weibull distributions for fitting diameter distributions of neem plantations in Northern Ghana. Forest Ecology and Management 103:1-7.

Návar, J. and Contreras, J. 2000. Ajuste de la distribucion Weibull a las estructuras diametricas de rodales irregulares de pino de Durango, México. Agrociencia: Rec. Nat. Ren. 34: 353-361.

Návar, J. and S. Corral. 2000. Modelling the weibull distribution parameters of unevenaged Pine and oak diameter structures of Durango, Mexico. International Conference on Forest Ecosystem Restoration. 10-12 April 2000. Vienna, Austria.

Richardson, D.M. and W.J. Bond. 1991. Determinants of plant distribution: evidence from pine invasions. American Naturalist 137: 639-668.

Sortk, N.E., Boyle, T.J.B, Dale, V., Eeley, H., Finegan, B., Lawes, M., Monokaram, N., Prabhu, R., and Soberon, J. 1997. Criteria and indicators for assessing the sustainability of forest management: Conservation of biodiversity. Center for International Forestry Research. Working Paper No. 17.

Vanclay, K.V. 1994. Modelling Forest Growth and Yield: Applications to Mixed Tropical Forests. CAB International. Wallingford, Oxon, UK. 312 p.

Zarnoch, S.J. and T.R. Dell. 1985. An evaluation of percentile and maximum likelihood estimators of weibull parameters. Forest Science 31(1): 260-268. 